\title{
The Problems of Social Studies Teachers in Junior High School with Online Learning During the Covid-19 Pandemic
}

\author{
Yuhanida Milhani ${ }^{*}$, Harun
}

\author{
Universitas Negeri Yogyakarta, Indonesia \\ *Corresponding author email: yuhanidamilhani.2021@student.uny.ac.id, yuhanida@uny.ac.id
}

\begin{abstract}
Online learning is essential to limit social interaction thus reducing the risk of coronavirus transmission. This study aimed to explore the implementation of social science learning in online learning, problems faced by teachers in social science learning, and efforts made by the teachers to address the issues. This research used a mixed-method approach with a triangulation mixed methods design. The primary informants for the qualitative inquiry were four teachers of social sciences studies in junior high school. The number of participants for the quantitative analysis was 53 junior high school social studies teachers recruited using accidental sampling. Data were collected using questionnaires, observations, and interviews. Data validity checking techniques were carried out by triangulation of sources. Data analysis was conducted using the Miles and Huberman method. The results of the studies indicate three significant findings. First, the teacher provided material using WhatsApp, youtube, and zoom and provided evaluation using quiz applications and google Forms during the online learning. Second, the problems faced by the teachers included lack of facilities and infrastructure, lack knowledge about IT, lack of social interaction of students, too much student workload, reduced allocation of time for lessons. Third, to solve the problems, teachers suggested optimizing the learning media, conducting contextual learning, improving cooperation of teachers and parents, reducing the burden of student assignments, and improving teaching materials. It is recommended to provide more supports for the teachers during online learning.
\end{abstract}

Keywords: online learning, problems, social studies teachers.

\section{INTRODUCTION}

Covid-19 began to spread in Indonesia around the end of March 2020 until finally declared as a pandemic or national disaster. Since its emergence in Indonesia, the covid-19 pandemic has had a very significant impact on various aspects of life. One of which is the aspect of education. With government policies that apply restrictions on activities involving large crowds, inevitably, the learning system becomes changed from the usual. Long-distance learning has become a new habit of life or commonly referred to as the new normal. Distance learning activities in schools are divided into three modes which were online learning, learners offline (off-network), and a combination of online and offline.
Each school certainly uses different ways of carrying out distance learning, among others influenced by the competence of teachers and students and available facilities and infrastructure in the form of gadgets and internet networks in the region. For example, schools located in cities tend to use online learning, because it has a strong internet network. Vice versa, schools located in the village tend to use offline learning because of the weak network in the location.

Learning Social knowledge is learning related to social relationships. Social science studies learning is also related to the interaction of fellow humans and communities in school and outside school. Distance learning has an impact on the learning process, especially in social science education. Several previous studies have raised the theme of online learning in the 
pandemic era. Among them is a research that is conducted to identify the implementation of online learning by collecting information from several sources[1]. The results of online learning in elementary students will be carried out properly if there is cooperation between teachers, students, and parents. There several reviews related to online learning systems [2]. This distance learning method is the most effective primary alternative to be done in pandemic times. A study [3], identify a picture of the implementation of online lectures on biology education. There are also writings from a study[4], that analyze how the picture of the implementation of online lectures for Biology students meets some basic facilities needed in online learning. Students are more independent and passionate in learning with learning conditions that are done flexibly, and with the enactment of online lectures will reduce the spread of Covid-19.

Problems come from English, namely "problematic," which means problem or problem. While in the Indonesian dictionary, problems mean things that have not been solved; which causes problems [5]. Syukir argues that a problem is a gap between hope and reality that is expected to be completed or can be needed. Through the explanation of the theory, it can be concluded that a problem is a problem that needs to be solved due to the achievement of a goal.

Social science subjects in Junior High School examine a set of events, facts, concepts, and generalizations related to social issues. At the junior high school level, social science subjects contain materials of Geography, History, Sociology, and Economics. Through the subjects of Social Sciences, learners are directed to become democratic and responsible Citizens of Indonesia and peace-loving citizens of the world.

Learning is a systematic effort made by teachers to realize the learning process effectively and efficiently, starting from planning, implementation, and evaluation [6]. According to Nasution, learning is an activity to organize or organize the environment as well as possible and connect it with learners so that the learning process occurs [7]. So, learning is the interaction of learners with educators and learning resources in a learning environment. Online learning is learning organized through web networks. Each course/ lesson provides material in video recordings or slideshows, with weekly tasks that must be done with a predetermined work time limit and various assessment systems [8].

Complaint after complaint of distance learning has been heard a lot from both teachers and parents of students from various news media, both mass media and internet social media. The main thing is the achievement of learning goals. Through the background exposure, the purpose of the research in this study was to identify problems of junior high school teachers in learning Social Sciences during the covid-19 pandemic. This research answered three main questions related to identifying problems of junior high school teachers in learning social sciences during the covid-19 pandemic, namely: (1) How to conduct online Social Science learning in the covid-19 pandemic, (2) What were the problems of junior high school Social Science teachers in online learning in the covid-19 pandemic, (3) How to solve the problem of junior high school Social Science teachers in learning online during the Covid-19 pandemic.

\section{METHODS}

This study used a mixed-method approach with a triangulation mixed methods design. The main informant for the qualitative inquiry was four teachers of Social Sciences studies in Junior High School. The number of respondents for the quantitative analysis was 53 junior high school social studies teachers recruited using accidental sampling. Data were collected using questionnaires, observations, and interviews. Data validity checking techniques are carried out by triangulation of sources - data analysis using Miles and Huberman.

Data analysis techniques used data reduction techniques which are forms of analysis that sharpen, classify, direct, dispose of unnecessary, and organize data so that conclusions can be drawn. Then the presentation of data or activities when a set of information is compiled, thus giving the possibility of conclusions [9]. Form the presentation of qualitative data in the form of narrative text (in the form of field notes), matrices, graphs, networks, and charts. Then the results of the analysis can be used to take action based on data reduction and data display.

\section{RESULTS AND DISCUSSION}

The results of this study are as follows: Implementation of distance IPS learning in Junior High School in the Covid-19 pandemic. Through the results of the author's interview with four teachers, the author gets information that the implementation of learning social knowledge online conducted with various media, including the teacher create a WA group for students as a medium of communication and delivery of information related to learning, which includes; subject matter, instruction of learning procedures, monitoring of students' learning progress, to learning evaluation. So at the time of the learning process, interaction between teachers and students is done through WA groups, starting from teachers explaining the material, assigning students related material to Q\&A related to things that students have not understood. For example, at the start of the lesson hours, the teacher greets and gives 
instructions in the WA group; "Assalamualaikum, good morning everyone. Please open the material about Social interaction. Read the material until it's finished, then observe your surroundings. Then write all sorts. Social interaction of milieu Each of you.".

The use of WhatsApp group media is beneficial in the interaction of teachers and students. Still, of course, there are very significant differences compared to the learning process directly. In distance learning interactions using this WA group, teachers are unable to monitor student activities directly, so teachers have difficulty providing motivation for students who lack enthusiasm in learning. In addition, active students will tend to master the course of learning, while passive students are only more passive and do not participate in WA group interactions because they get less motivation.

In addition to using WA media, teachers also make videos or search for learning videos on YouTube that match the learning material. Teachers share a video link with students. Then students are asked to watch the learning video. Then afterward, students are asked to conclude the learning video that has been watched.

Table 1 The online learning process for social studies

\begin{tabular}{|l|c|}
\hline Learning Process & $\begin{array}{l}\text { Response } \\
\text { (Persentase) }\end{array}$ \\
\hline Using the Online Quiz & 73,6 \\
\hline Explain material using YouTube & 64,2 \\
\hline $\begin{array}{l}\text { Explain material and discuss using } \\
\text { zoom meeting }\end{array}$ & 75,5 \\
\hline Using google classroom & 77,4 \\
\hline $\begin{array}{l}\text { Using LMS (Learning Management } \\
\text { System) }\end{array}$ & 13,2 \\
\hline
\end{tabular}

Teachers are constrained by time when developing a video because it requires long preparation, from preparing the material and then designing content and video editing. So teachers are more often looking for videos relevant to the material on YouTube because it is more time-efficient. In addition, another obstacle is that even though they have used video media, not necessarily students will immediately understand the material taught because to understand the material and the linkage of video with teacher material also needs to provide an explanation of the material to students. Of course, elementary school-age students still need guidance in carrying out activities and tasks related to materials. For example, in the material on Social and Cultural Diversity in Indonesia, teachers provide video links that illustrate the various cultures found in Indonesia. Students were asked to watch a video on a link, then assigned to observe and write down various social and cultural diversity in their respective areas.

So this YouTube video learning media is just a supporting medium for students in learning. It is hoped that learning using this video media can represent students' needs about the concrete picture of the subject matter. Then, of course the teacher must be careful in choosing the video given to students in learning because the video material must be completely in accordance with the subject matter. Sometimes teachers also take advantage of zoom meetings in conducting their learning. The goal is for teachers to provide material explanations and discuss virtual face-to-face with students. So that the material taught can be more easily understood by students.

Table 1 How to do an assessment of evaluation

\begin{tabular}{|l|c|}
\hline Assessment or evaluation of learning & $\begin{array}{c}\text { Response } \\
\text { (Persentase) }\end{array}$ \\
\hline Using application Quiz online & 49,1 \\
\hline Using google form & 94,3 \\
\hline Collect assignments via WhatsApp & 71.7 \\
\hline
\end{tabular}

To conduct daily evaluations, teachers use quiz applications to measure students' ability to answer questions. The quiz can also be used as a game about the same problem as playing hago on brain quiz games. So that students feel like they are doing a game while working on it.

In addition to using quiz applications, sometimes teachers also use google Forms in evaluating learning by using a predetermined time limit. The use of this time limit aims in addition to training knowledge, and students are trained to make the best use of time in working on problems

Table 3. Problems faced by junior high school social studies teachers in online learning during the covid-19 pandemic

\begin{tabular}{|l|c|}
\hline $\begin{array}{l}\text { The problem faced by junior high school } \\
\text { social studies teachers }\end{array}$ & $\begin{array}{l}\text { Response } \\
\text { (Persentase) }\end{array}$ \\
\hline Lack of infrastructure & 47,2 \\
\hline Teacher lack control of IT & 20,8 \\
\hline Lack of social interaction & 94,3 \\
\hline $\begin{array}{l}\text { The burden of student assignments is too } \\
\text { much, }\end{array}$ & 39,6 \\
\hline Less time allocation for lessons & 60.4 \\
\hline
\end{tabular}

Some of the problems found by researchers include Lack of facilities and infrastructure, in the implementation of distance learning, especially online learning certainly needed facilities in the form of gadgets such as smartphones and adequate internet signals. In fact, there are still many students who do not have a smartphone with sufficient specifications, so that it is quite limited in use, for example, to do zoom meetings. Te zoom application requires a fairly good specification of the phone from RAM and storage space. In addition, quota and signal constraints are also very influential. The amount of quota load needed in zooming meetings weighs heavily on students and parents, and inadequate signal conditions also certainly hinder students' smooth learning, especially if the student lives in a rural area.

Teachers who lack control of IT but teachers who do not master IT certainly inhibit the smooth process of distance learning, especially online learning. Usually, 
the teachers who do not master IT are senior teachers or elderly because they have not used and do not even know IT in the past. So to learn various kinds of IT science and apply it at once is certainly very difficult, especially if you consider the age range of senior teachers. Of course, learning a very new IT science for them will be more complex than young teachers. The media used and controlled by senior teachers is WhatsApp because it is used in everyday life. Lack of teacher creativity in carrying out online learning using only one medium, namely WA, makes learners less effective because students need a variety of social media that are more varied to support the achievement of learning goals.

Lack of social interaction, elementary school students are students whose learning is accompanied by play and requires social interaction to develop their abilities, even more so in IPS subjects related to the social sciences. In addition to learning from teachers, students can also learn from friends in terms of knowledge and how to behave through social interaction. Because the purpose of learning is also in addition to developing cognitive abilities also aims to create affective and psychomotor skills so as to make students of character.

Difficult to give concrete images to students, in distance learning with conditions of social restrictions, certainly quite difficult for teachers in providing concrete images related to materials, such as IPS material about history. Teachers should be able to invite students to visit museums or historical sites so that students can see directly the historical relics they have learned in school.

The burden of student assignments is too much. Limited access meets directly, causing teachers to give more assignments than explaining the material. So those students are very burdened by the tasks that are given every day, which then cause complaints from both students and parents of students. With the condition of feeling burdened, it certainly greatly affects the motivation of learning students, so it often happens precisely to the parents of students who do the task.

Reduced allocation of lesson hours. During distance learning, junior high school students' lesson hours that were initially 45 minutes were trimmed to 30 minutes. With a short time, of course, teachers are quite difficult in providing education to students, so teachers more often give assignments than education in the form of explanations related to the material.

Lack of parental supervision and supervision. It is undeniable, distance learning conducted by elementary school students certainly requires parental assistance and supervision. Because elementary school students still need attention and guidance in learning. But the busyness and lack of parental understanding related to student learning materials make students less supervised. With a lack of supervision and guidance, students become less motivated and focused on learning. This can certainly have an impact on the student's understanding of the material, which is the student's understanding of the material is the goal of learning.

\section{CONCLUSION AND SUGGESTION}

Through the presentation of the results of the above research, it can be concluded that the implementation of Social Science learning of Junior High School online during the covid-19 pandemic, among others; 1) providing material using WhatsApp, 2) explaining the material using YouTube, 3) explaining the material and discussing using zoom, 4) evaluating learning using Quiz applications, 5) evaluating learning using google form.

Problems of junior high school social science teachers online in the time of the covid-19 pandemic include; 1) lack of facilities and infrastructure, 2) teachers lacking control of IT, 3) lack of social interaction, 4) too much student task load, 5) reduced allocation of lesson hours.

This research provides several suggestions related to the problematic solutions of junior high school social science teachers online in the covid-19 pandemic include the following; 1) optimization of learning media, 2) Using contextual learning, 3) teacher and parent cooperation, 4) reducing the burden of student assignments that are tested, 5) making learning modules interesting.

\section{REFERENCES}

[1] D, W Aji Fatm, Dampak Covid-19 Terhadap Implementasi Pembelajaran Daring di Sekolah Dasar (Edukatif: Jurnal Ilmu Pendidikan, Vol.2(1), 2020.

[2] H, L Devi, "Pembelajaran Pada Masa Pandemi Covid-19" (Jurnal Teknologi Pendidikan, Vol. 22 No. 1).

[3] F, S. Rahayu Rahman, "Pembelajaran Online di Tengah Pandemi Covid-19" (IJES: Indonesian Journal of Educational Science, Vol. 2(2), 2020.

[4] S, Ali and A. Hamidah, "Pembelajaran Daring di Tengah Wabah Covid-19", Biodik: Jurnal Ilmiah Pendidikan Biologi, Vol. 6(2), 2020.

[5] Debdikbud, Kamus Besar Bahasa Indonesia. Jakarta: Bulan Bintang, 2002. 
[6] A Nata, Perspektif Islam Tentang Strategi Pembelajaran, Jakarta: Aqib, Z. Model-Model, Media, dan Strategi Pembelajaran Kontekstual (Inovatif). Bandung: Yrama Widya, 2013.

[7] S. Nasution, Asas-Asas Mengajar. Jakarta: Bumi Aksara. 1995.

[8] M. N. Qomarudin, Esensi Pengembangan Pembelajaran Daring. Yogyakarta: Deep Publish, 2016.

[9] M. B. Miles, A. M. Huberman, and J. Saldana, Qualitative data analysis: a methods sourcebook, $3^{\text {rd }}$ Ed. Thousand Oaks, CA: SAGE, 201 